\title{
Validation of a Pampa Corte simulation model for hair sheep production in a tropical silvi-pastoral system in Chiapas, Mexico
}

\author{
A.C Rebollo-Morales ${ }^{1}$, G. Yong-Ángel ${ }^{1}$, J. Velarde-Guillén ${ }^{2}$, S. \\ Carrillo-Hernández ${ }^{2}$, V.C.P. Silveira ${ }^{3}$, C.M. Arriaga-Jordán ${ }^{2}$ and \\ F. López-González ${ }^{2 *}$
}

\begin{abstract}
${ }^{1}$ Facultad de Medicina Veterinaria y Zootecnia, Universidad Autónoma de Chiapas, Carr. Emiliano Zapata Km. 8, C.P. 29060 Tuxtla Gutiérrez, Chiapas, México. ${ }^{2}$ Instituto de Ciencias Agropecuarias y Rurales (ICAR), Universidad Autónoma del Estado de México, Campus UAEM El Cerrillo, El Cerrillo Piedras Blancas, 50090 Toluca, Estado de México, México. ${ }^{3}$ Departamento de Educação Agrícola e Extensão Rural, Universidade Federal de Santa Maria (UFSM), 97105-900 Santa Maria, RS, Brasil.

*Corresponding Author: flopezg@uaemex.mx
\end{abstract}

Journal of Livestock Science (ISSN online 2277-6214) 12: 246-254

Received on 21/5/21, Accepted on 17/7/21, Published on 29/7/21

doi.10.33259/JLivestSci.2021.246-254

\begin{abstract}
Most sheep production systems are based on grazing medium to low quality grasslands, with or without supplements. In tropical areas, the inclusion of legume shrubs and trees like Leucaena (Leucaena leucocephala) in silvopastoral systems associated with grassland are an alternative to improve their productivity. An efficient way to test the impact of these innovations is by simulation models. Therefore, the objective was to validate the Pampa Corte model developed in Brazil adapted to sheep growth under Mexican conditions to simulate the effect of the inclusion of Leucaena in a silvopastoral system based on Guinea grass (Megathyrsus maximus cv. Tanzania). Three scenarios were simulated, T1 = 100\% Guinea grass, $\mathrm{T} 2=80 \%$ Guinea grass $+20 \%$ Leucaena, and T3 $=60 \%$ Guinea grass and $40 \%$ Leucaena on a dry matter basis. Validation of the model was with data from a previous experiment on lamb growth fed a total mixed ration. Evaluation was from lineal regressions of simulated results over observed data. Results showed a coefficient of determination $\left(\mathrm{R}^{2}\right)$ of 0.94 between observed and estimated figures. The simulation model also showed that as the proportion of Leucaena increases in the silvopastoral system, the daily live weight gain (DWG) also increases. The model provided good results for lamb growth in silvopastoral systems based on Guinea grass with the inclusion of Leucaena and validated with data from feedlot lambs fed a total mixed ration, both for extensive silvopastoral systems with $20 \%$ Leucanea as for intensive silvopastoral systems with up to $40 \%$ of Leucaena inclusion.
\end{abstract}

Keywords: Leucaena leucocephala; Megathyrsus maximus; Pelibuey hair sheep; silvopastoral systems, Pampa Corte simulation model. 


\section{Introduction}

Livestock rearing has a most important role in rural livelihoods and economies worldwide, particularly in developing countries (Herrero et al. 2012); where small ruminant (goats and sheep) production systems enable small-scale farmers to overcome poverty through a more inclusive economic growth thereby improving social equity (Makkar 2016). Sustainable intensification of livestock systems has been proposed as the way forward to increase their contribution to rural livelihoods, to meet the increased global demand for foods of animal origin, and to reduce their environmental footprint (Rao et al. 2015). Sheep production is an important activity in the agricultural economy of Mexico both by providing food for the farming families and their communities, as well as contributing to generate income from the sale of sheep and sheep products (Pérez-Luna et al. 2011). Sheep production in Mexico, has experienced substantial growth over the last decade, with a national sheep flock that increased from 8.1 to 8.7 million head, and a growth in meat production from 54,830 $\mathrm{t}$ in 2010 to 65,150 $\mathrm{t}$ in 2020 (SIAP 2021), representing an $1.8 \%$ increase in sheep meet production per year, higher than the current rate of population growth in Mexico currently at less than $1.1 \%$. However, this production does not meet internal demand so that Mexico imports every year between 14\% (Hernández-Marín et al. 2017).

Sheep production systems in Mexico therefore require changes and innovation to meet current and future demands through a sustainable intensification, as it has been shown that small improvements in the livestock systems of developing countries can have a high impact in enhancing productivity (Makkar 2016). In the tropical areas of Mexico, sheep production has developed over the last 60 years towards mutton and lamb meat production through hair sheep breeds given their adaptation to the high temperatures and humidity of these areas (Quintanilla-Medina et al. 2018), based predominantly on the Pelibuey breed, but other hair sheep breeds as well, given their adaptability to a range of environmental factors, being hardy, with no seasonality in their reproduction, high prolificity, and parasite resistance as favourable traits (Chay-Canul et al. 2019).

The best way to improve meat production in these hair sheep systems is by improving their feeding. In these areas, flocks graze pastures of low and medium quality tropical grasses, with or without other feed supplementation (Chay-Canul et al. 2011) and are subject to nutritional stress during the dry season when forage resources die out and are scarce as is common in tropical and subtropical areas of the world like Ethiopia (Gebre et al. 2020). The types of shrubs and feed additives are important for the growth of sheep in tropical grassland and rangeland system (Mukhongo et al 2014; Martinez et al., 2015). The inclusion of legume shrubs or trees as Leucaena leucocephala under a silvopastoral system improves the nutritional status of flocks and herds as these provide browse high in nutrients as protein, vitamins and minerals (Barros-Rodríguez et al. 2012), representing a viable alternative. Silvopastoral systems are a good example of sustainable intensification taking place to meet growing demands for livestock products (Murgueitio et al. 2014). There is a higher production and availability of better quality feed for livestock, which favours increased productivity and positive effects on biodiversity, health and animal welfare (Broom 2017).

Mathematical models in agricultural research and planning are important because they support scientific information, it is also useful to forecast results in specific situations and conditions, mathematical models in animal nutrition and production enables the integration of scientific knowledge to develop tools for decision making to improve animal production (Tedeshi et al. 2010). These models are reliable and provide information to visualize different production alternatives, representing a first step in the strategic planning of production systems (Trevisan et al. 2009). In sheep production, simulation models predict nutritional requirements, as well as productive, reproductive and economic performance (Gebre et al. 2020). The Pampa Corte is a dynamic and mechanistic model developed in Brazil to simulate live weight gain in beef cattle (Silveira 2011); and validated for sheep production for conditions in Spain (Silveira et al. 2012). Its adaptation to sheep production systems in Mexico represents an option for the rapid and reliable estimation of growth under different feeding scenarios. Initially, the Pampa cut model was developed for cattle and adapted to simulate the growth of lambs in a dynamic and mechanistic way. The Pampa cut model has a high degree of precision in the weights of the sheep, until the sacrifice of the animal, one of the limitations is that it does not contemplate sanitary problems that the animals have.

Therefore, the objective was to validate a simulation model of the productive performance of growing Pelibuey hair sheep in a silvopastoral system under tropical conditions based on Leucaena (Leucaena leucocephala cv. Cunningham) and Guinea grass (Megathyrsus maximus formerly Panicum maximum cv. Tanzania) and to evaluate the effect of the Leucaena inclusion. 


\section{Materials and methods \\ Model}

The model developed by Silveira (2012) that simulates sheep growth was adapted to the conditions of this study. This model is divided in two sub-models: 1) feed intake and digestion based on Illius and Gordon (1991) and Sniffen et al. (1992), and 2) prediction of body weight change from equations by ARFC (1992) and CSIRO (2007). Detailed characteristics of the model are reported by Silveira (2012). The model was run on a proprietary spreadsheet programme.

Data base for the validation of the Pampa Corte model

Validation of the model was from a data base from a previous trial (Pérez-Luna et al. 2011) to evaluate growth and fattening of lambs kept in total confinement and fed total mixed rations. That trial took place in a tropical area at an altitude of $420 \mathrm{~m}$, a warm sub-humid climate, with a mean overall annual temperature of $26^{\circ} \mathrm{C}$, and $990 \mathrm{~mm}$ rainfall, mostly in the summer (April - October) rainy season.

The trial used 30 entire male mixed bred lambs form Pelibuey, Dorper and Katahdin hair sheep breeds with a mean live weight of $18.0 \pm 3.0 \mathrm{~kg}$, de-wormed previous to the trial and a multivitamin shot (vitamins A, D, and E) applied. Sheep were housed in a shaded (75\% of the area) loose pen with free access to water at all times. The trial lasted 90 days, divided in a 45 day growth stage 1 and 45 day fattening stage 2. Complete mixed rations made from maize straw, maize grain, wheat bran, soyabean meal, feather meal, and minerals were prepared for each stage, formulated to meet the nutrient requirements of sheep in each stage (NRC 2007). Feeding was at 8:00 and 16:00 h offering 10\% more intakes recorded in the previous day to ensure ad libitum intake. Lambs were weighed every 7 days with an electronic portable weighbridge, and live weight changes expressed as daily weight gain (DWG) in $\mathrm{g} / \mathrm{lamb} /$ day. Dry matter intake (g DM/lamb/day) was from the difference between offered and refused DM. Sheep gained a mean $21.0 \mathrm{~kg}$ over the 90-day trial representing a mean DWG of $233 \mathrm{~g} / \mathrm{lamb} / \mathrm{day}$ (Pérez-Luna et al. 2011).

\section{Simulation of the silvopastoral system}

Determination of the chemical composition of foliage (leaves and twigs) from Leucaena simulating browse and Guinea grass herbage from simulated grazing was following standard procedures. Dry matter (DM), crude protein (CP) and ashes followed AOAC (2004) methods. Acid detergent fibre (ADF) and neutral detergent fibre (NDF) were determined following methods by Van Soest (1967).

Results from chemical analyses of feeds were used to simulate three levels of Leucaena inclusion in the system: T1 -100\% Guinea grass, T2 - 80\% Guinea grass + 20\% Leucaena, and T3 - 60\% Guinea grass $+40 \%$ Leucaena. The model generated three diets that met nutritional requirements of growing lambs (NRC 2007).

Statistical analyses Lineal regressions were performed between observed data from Pérez-Luna et al. (2011) and the predicted values from the model.

\section{Results \\ Model validation}

Simulation results for dry matter intake (DMI) of the trial reported by Pérez-Luna et al. (2011) showed a coefficient of determination $\left(\mathrm{R}^{2}\right)$ of 0.75 (Figure 1); which indicates that the model was well calibrated and adjusts to reality. On the other hand, the simulated daily live weight gain (DWG) showed an $\mathrm{R}^{2}$ of 0.38 (Figure 2), indicating the need for a better calibration for this part of the model.

The overall $\mathrm{R}^{2}$ of the simulation was 0.94 (Figure 3 ) higher than the $\mathrm{R}^{2}$ reported by Pérez-Luna et al. (2011) of 0.74 for observed results in their trial. This means that although a part of the model does not provide reliable estimates as the model over-estimates live weight gain results in relation to DMI.

\section{Simulation of the silvopastoral system}

Table 1 sows the chemical analyses of Guinea grass herbage and Leucaena foliage. Figure 1 shows the relationship between observed dry matter intake (DMI) and simulated DMI. Figure 2 shows results of the simulation between observed daily live weight gain (DWG) and predicted DWG, and Figure 3 shows the relationship between simulated dry matter intake and daily live weight gains. Figures 4A, 4B, and 4C show the simulated dry matter intake (DMI) over time (4A), daily live weight gain (DWG) over time (4B) and over DMI (4C); and Figure 5, show the relationship between DWG and DMI. Besides the good fit between observed and predicted values, the simulated scenarios showed that as the proportion of Leucaena increased in the diet, DWG increased. 
Table 1. Chemical composition of Leucaena (Leucaena leucocephala) and Tanzania Guinea grass (Megathyrsus maximus)

\begin{tabular}{|l|c|c|}
\hline & Leucaena leucocephala & Megathyrsus maximus \\
\hline DM, g/kg DM & 930 & 896 \\
\hline CP, g/kg DM & 252 & 81 \\
\hline Ash, g/kg DM & 107 & 129 \\
\hline EE, g/kg DM & 68 & 18 \\
\hline NDF, g/kg DM & 514 & 760 \\
\hline ADF, g/kg DM & 362 & 468 \\
\hline
\end{tabular}

$\mathrm{DM}=$ Dry matter, $\mathrm{CP}=$ Crude protein, $\mathrm{EE}=$ Ether extract, $\mathrm{NDF}=$ Neutral detergent fibre, $\mathrm{ADF}=$ Acid detergent fibre .

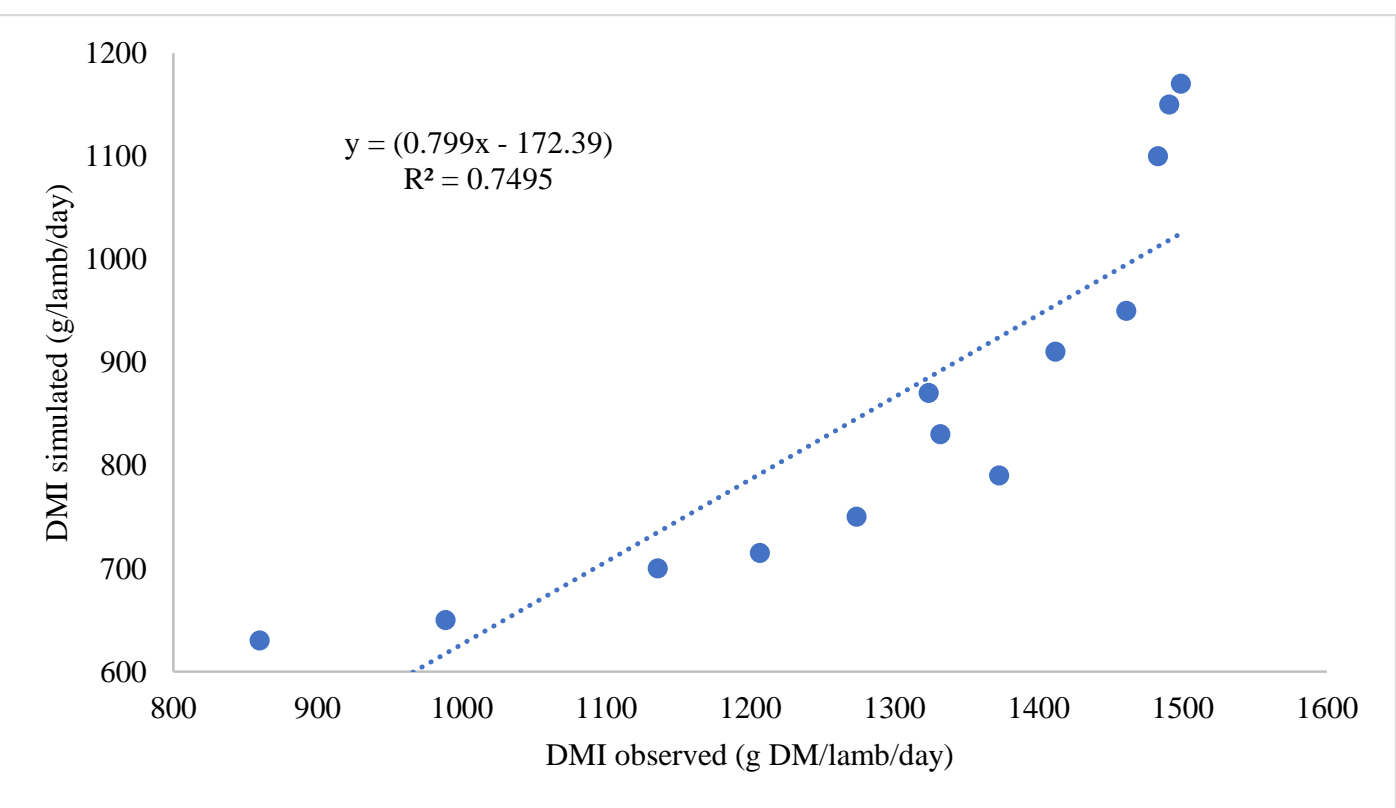

Fig 1. Observed and simulated dry matter intake (DMI)

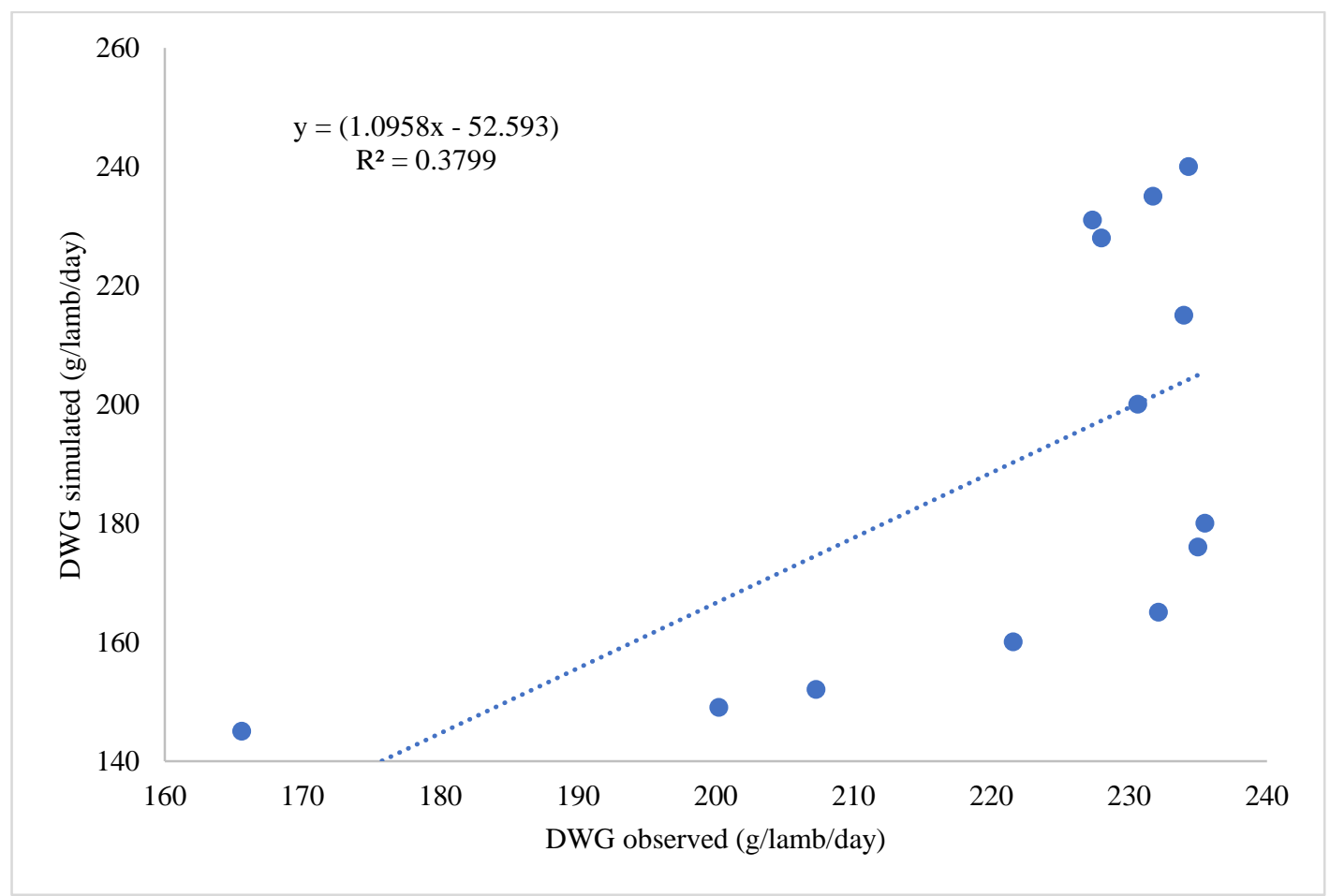

Fig 2. Observed and simulated daily live weight gain (DWG). 


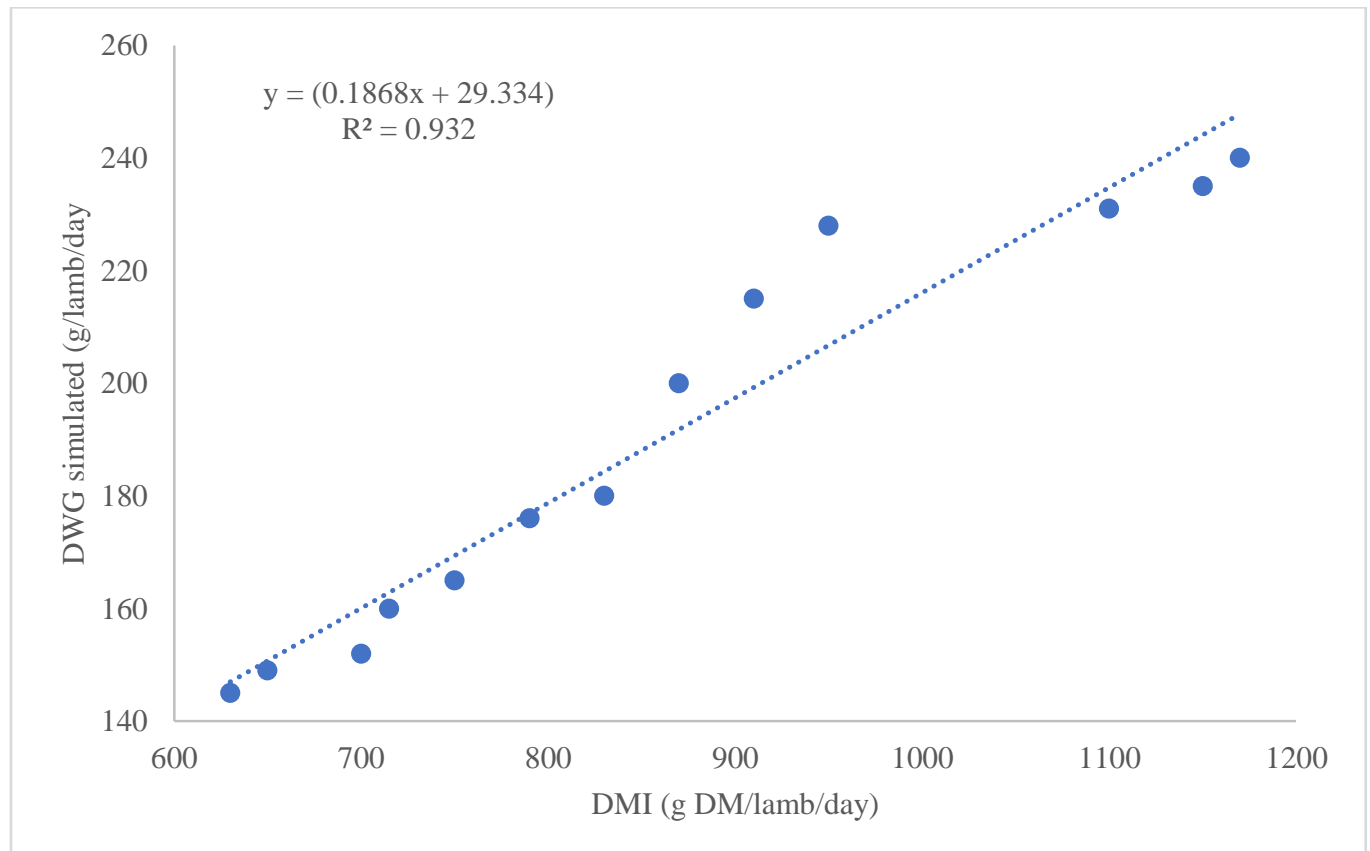

Fig 3. Relationship between simulated dry matter intake (DMI) and daily live weight gain (DWG).

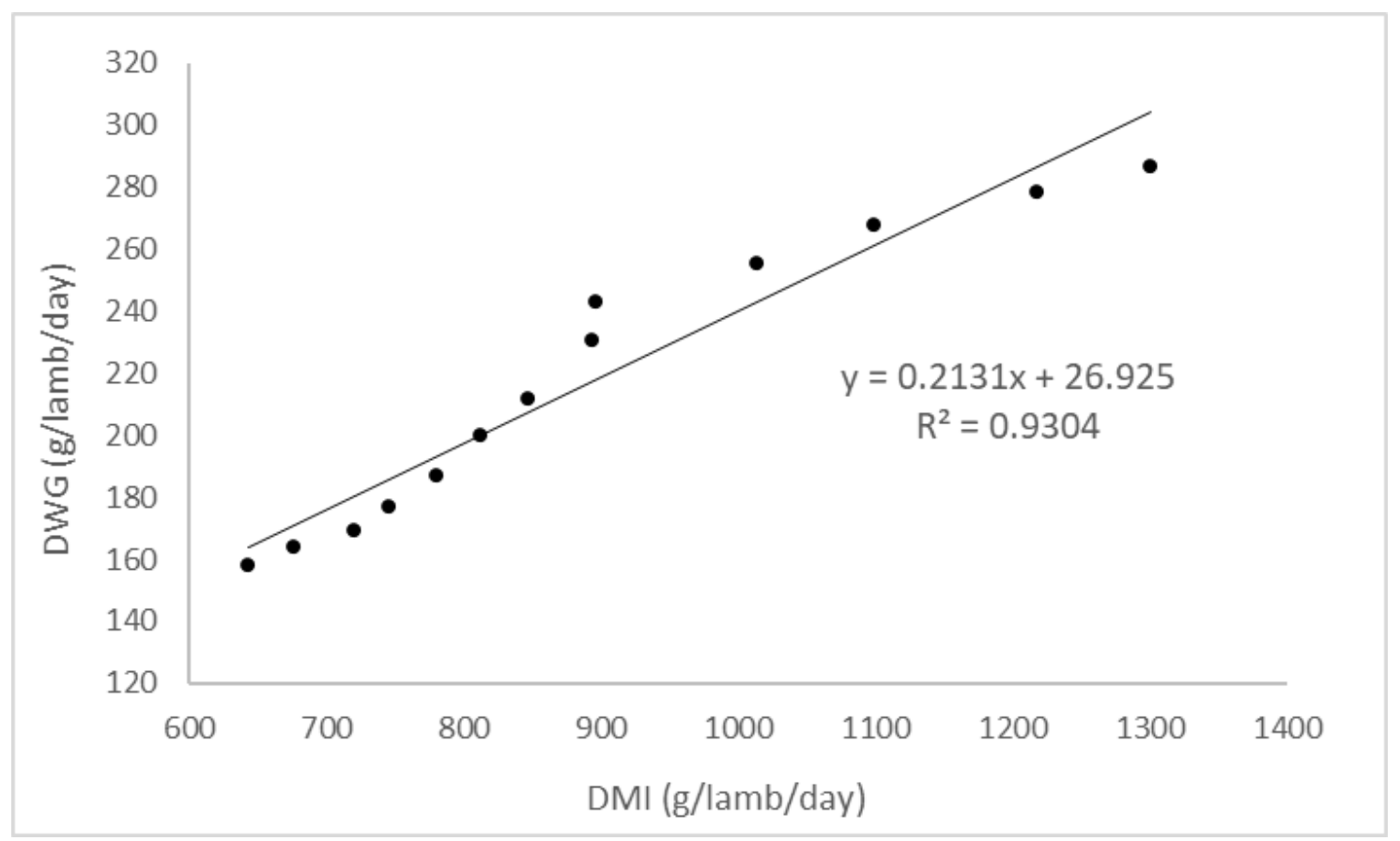

Fig 5. Relationship between daily live weight gain (DWG) and dry matter intake (DMI). 

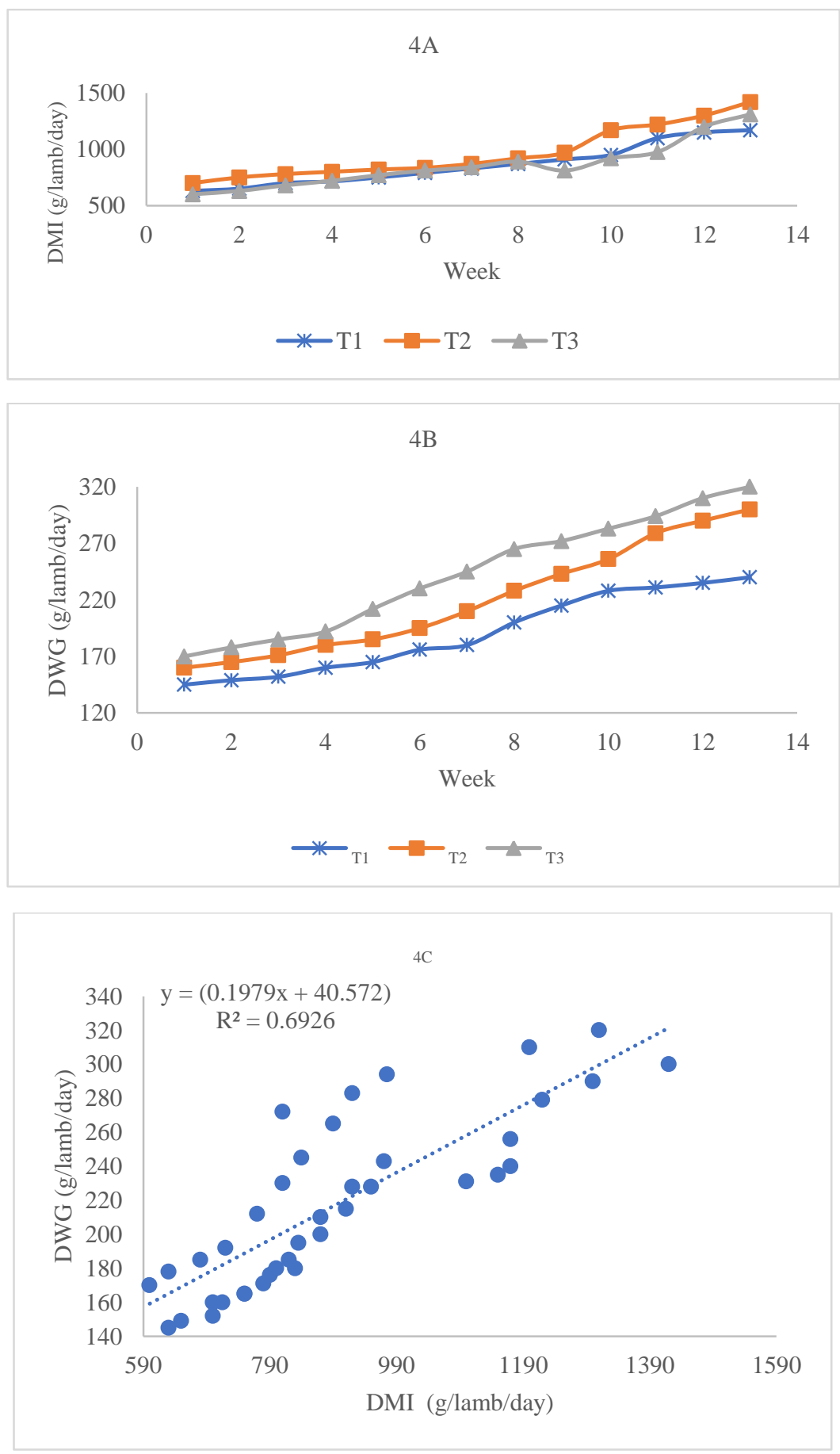

T1: $100 \%$ Guinea grass; T2: 80\% Guinea grass and 20\% Leucaena; T3 : 60\% Guinea grass and 40\% Leucaena

Fig 4. Simulated dry matter intake (DMI) over time (4A), daily live weight gain (DWG) over time (4B) and over DMI (4C)

\section{Discussion}

Model validation

The coefficient of determination $\left(\mathrm{R}^{2}\right)$ for dry matter intake (DMI) was higher than estimations from NRC (2007) at 0.63 or than reports by Duarte-Vera et al. (2009) with $\mathrm{R}^{2}$ coefficients between 0.48 and 0.54 , or those reported by Maia et al. (2014) at 0.46, but lower than equations assessed by Vieira et al. (2013) who reported a mean $\mathrm{R}^{2}$ of 0.81 .

The coefficient of determination was also lower than reported by Silveira et al. (2012), using the same model, who found a high correlation between simulation results and observed data for lambs 
finished at 45 days of the Aragonesa and Churra Tensina breeds with $R^{2}=0.87$ and $R^{2}=0.92$, respectively. On the other hand, regression results of the simulated DWG values over those observed were similar to reported by Silveira et al. (2012), where simulations over observations on live weight gain for lambs over 60 days old had $\mathrm{R}^{2}$ values of 0.70 for Aragonesa breed and 0.77 for the Curra Tensina breed.

These results show that the model, developed for extensive sheep production systems (Silveira et al., 2012), it does provide acceptable results for silvopastoral systems based on Guinea grass with the inclusion of Leucaena, and validated with data from feedlot lambs fed a total mixed ration.

\section{Simulation of the silvopastoral system}

Results for chemical composition of Guinea grass and Leucaena are similar to those observed in the study area. Jiménez-Santiago et al. (2019) reported for Guinea grass higher values for CP (124 g/kg $\mathrm{DM}$ ) and ADF (490 g/kg DM), but lower in NDF (712 g/kg DM); while Leucaena was lower in CP (261 $\mathrm{g} / \mathrm{kg} \mathrm{DM}$ ) and higher in NDF (462) than values reported herein. Barros-Rodríguez et al. (2012) reported higher contents of CP (291 g/kg DM) and lower NDF (372 g/kg DM) in Leucaena, and higher CP content $(114 \mathrm{~g} / \mathrm{kg} \mathrm{DM})$ and lower NDF (627 g/kg DM) in Guinea grass; and Villanueva-Partida et al. (2019) observed lower concentrations of NDF for Leucaena (376 g/kg DM) and Guinea grass (552 g/kg DM) with CP values similar to the work herein reported.

In terms of DMI and DWG, simulated results indicate that T3, a 60 Guinea grass: $40 \%$ Leucaena proportion, is the best option. However, when the metabolizable energy (ME) content of the diet is higher than $11 \mathrm{MJ} \mathrm{ME} / \mathrm{kg}$ DM, DMI decreases which may affect the simulation of daily live weight gain (Silveira et al., 2012).

Results herein reported where there is higher DWS as the proportion of Leucaena increases in the diet, are in agreement with reports by Boughalmi et al. (2014) in that lambs in silvopastoral systems that included Leucaena had higher live weight gains than those without Leucaena but supplemented with commercial concentrate. These authors also reported that the meat had a more beneficial profile of fatty acids when Leucaena was included in the diet.

Results presented were validated with data from a feedlot experiment. However, in under grazing conditions, the model may be adapted to simulate sheep behaviour, in terms of preference for grazing and occasional browsing Brand (2000). Candelaria-Martínez et al. (2017) reported that Leucaena comprised $20 \%$ of available biomass in extensive tropical silvopastoral systems where Leucaena is the main browse shrub. This would mean that T2, with $20 \%$ inclusion of Leucaena, better simulates forage conditions for sheep in these silvopastoral systems. However, under intensive silvopastoral systems as described by Azuara-Morales et al. (2020) where Leucaena was between 35 and $43 \%$ of biomass, the T3 scenario $(60 \%$ Guinea grass and $40 \%$ Leucaena) provided a good simulation. The Pampa cut model has been used with precision in other works, mainly with cattle, for which we consider that it should be developed further, both for research and for work on farms.

Conclusion

The simulation model correctly predicts dry matter intake, but not daily weight gain, however, the general model obtains a high correlation greater than $90 \%$ and adapts well to the reality of silvopastoral systems.

\section{Acknowledgments}

Authors express their gratitude to Dr. Esaú de Jesús Pérez-Luna for providing the data base for the validation of the simulation model investigated. Our appreciation also to the Mexican Council for Science and Technology (Consejo Nacional de Ciencia y Tecnología - CONACYT) for the postgraduate studies grant for Adriana Cecilia Rebollo-Morales (grant CVU 380322) and the postdoctoral grant for José Velarde-Guillén (postdoctoral grant CVU 482130).

\section{Conflicts of interest/Competing interests}

\section{Ethics approval}

The authors declare that they have no conflict of interest.

Research did not involve work with animals or persons, and followed guidelines accepted by Universidad Autónoma de Chiapas.

\section{References}

(1) AFRC, Agriculture and Food Research Council, 1993. Energy and Protein Requirements for Ruminants. An advisory manual prepared by the AFRC Technical Committee on Response to Nutrients, (CAB International, Wallinford, UK).

(2) AOAC- Association of Official Analytical Chemist, 2004. Official methods of analysis. Arlington, VA.

(3) Azuara-Morales I, López-Ortiz S, Jarillo-Rodríguez J, Pérez-Hernández P, Ortega-Jiménez E, Castillo-Gallegos E, 2020. Forage availability in a silvopastoral system having different densities 
of Leucaena leucocephala under Voisin grazing management. Agroforestry Systems 94: 17011711. DOI:10.1007/s10457-020-00487-5

(4) Barros-Rodríguez M, Solorio-Sánchez J, Ku-Vera J, Ayala-Burgos A, Sandoval-Castro C, Solís-Pérez G, 2012. Productive performance and urinary excretion of mimosine metabolites by hair sheep grazing in a silvopastoral system with high densities of Leucaena leucocephala. Tropical Animal Health and Production 44: 1873-1878. DOI:10.1007/s11250-012-0150-0

(5) Boughalmi A, Araba A, Yessef M, Elamiri B, 2014. Système de production et contraintes de durabilité de la filière viande ovine dans la province de Bouelemane. In: M. Chentouf, A. LópezFrancos, M. Bengoumi and D. Gabiña (eds), Technology creation and transfer in small ruminants: roles of research, development services and farmer associations. (CIHEAM/INRAM/FAO, Options Méditerranéennes : Série A. Séminaires Méditerranéens; $n$. 108: 415-419.

(6) Brand TS, 2000. Grazing behavior and diet selection by Dorper sheep. Small Ruminant Research 36: $147-158$.

(7) Broom DM, 2017. Invited Review: Components of sustainable animal production and the use of silvopastoral systems. Brazilian Journal of Animal Science 46: 683-688.

(8) Candelaria-Martínez B, Rivera-Lorca JA, Flota-Bañuelos C, 2017. Disponibilidad de biomasa y hábitos alimenticios de ovinos en un sistema silvopastoril con Leucaena leucocephala, Hibiscus rosa-sinensis y Cynodon nlemfuensis. Agronomía Costarricense 41: 121-131.

(9) Chay-Canul AJ, Aguilar-Urquizo E, Parra-Bracamonte GM, Piñeiro-Vazquez ÁT, Sanginés-García JR, Magaña-Monforte JG, García-Herrera RA, López-Villalobos N, 2019. Ewe and lamb preweaning performance of Pelibuey and Katahdin hair sheep breeds under humid tropical conditions. Italian Journal of Animal Science 18: 850-857. DOI:10.1080/1828051x.2019.1599305

(10) Chay-Canul AJ, Ayala-Burgos AJ, Ku-Vera JC, Magaña-Monforte JG, Ferrell CL, $2 \mathrm{O} 1$. Metabolizable energy intake and changes in body weight and body condition of Pelibuey ewes fed three levels of roughage diets under tropical conditions. Tropical and Subtropical Agroecosystems 14: 777-786.

(11) CSIRO, Commonwealth Scientific and Industrial Research Organisation, 2007. Nutrient requirements of domesticated ruminants, (CSIRO Publishing, Collingwood, Autralia.

(12) Duarte-Vera F, Sandoval-Castro C, Sarmiento-Franco L, 2009. SRNS model adequacy for body weight gain predicting in growing Pelibuey lamb males. Archivos de Zootecnia 58: 671-681.

(13) Gebre KT, Wurzinger M, Gizaw S, Haile A, Rischkowsky B, Sölkner J, 2020. Evaluation of increased feed supply and different fattening strategies for an Ethiopian sheep population by system dynamics modelling. Animal Production Science 60: 2050-2059. DOI:10.1071/an19546

(14) Hernández-Marín JA, Valencia-Posadas M, Ruíz-Nieto JE, Mireles-Arriaga AI, Cortez-Romero C, Gallegos-Sánchez J, 2017. Contribution of sheep breeding to the livestock sector in Mexico. Agro Productividad 10: 87-93.

(15) Herrero M, Grace D, Njuki J, Johnson N, Enahoro D, Silvestri S, Rufino MC, 2012. The roles of livestock in developing countries. Animal 7: 3-18 DOI:10.1017/s1751731112001954

(16) Illius AW, Gordon I, 1991. Prediction of intake and digestion in ruminants by a model of rumen kinetics integrating animal size and plant characteristics. Journal of Agricultural Science 116: 145-157.

(17) Jiménez-Santiago Á, Jimenez-Ferrer G, Alayón-Gamboa A, Pérez-Luna EDJ, Piñeiro-Vázquez ÁT, Albores-Moreno S, Pérez-Escobar MG, Castro-Chan R, 2019. Quantifying ruminal fermentation and methane production using the in vitro gas technique in the forages of a sheep silvopastoral system in Chiapas, Mexico. Revista Mexicana de Ciencias Pecuarias 10: 298-314.

(18) Maia ISG, Pereira ES, Pinto AP, Mizubuti IY, de Azambuja Ribeiro EL, de Souza Carneiro MS, Campos AC, Gadelha CR, Júnior JNR, 2014. Intake, evaluation of small ruminant nutrition system model and prediction of body composition of Santa Ines lambs fed diets with different levels of energy. Semina: Ciências Agrárias 35: 2579-2596. DOI: 10.5433/16790359.2014v35n4Sup11p2579

(19) Makkar HPS, 2016. Smart livestock feeding strategies for harvesting triple gain - the desired outcomes in planet, people and profit dimensions: a developing country perspective. Animal Production Science 56: 519 - 534. DOI: 10.1071/AN15557.

(20) Martínez ME, de la Barra R, de la Fuente F, 2015. Effect of early creep feeding in the performance of Chilota breed lambs. Journal of Livestock Science (ISSN online 2277-6214) 6:56-64

(21) Mukhongo DM, Mwai O, Tapio M, Muigai A, 2014. Genetic Diversity and Population Structure of the Indigenous Sheep in Kenya Based on Microsatellite Analysis: Implications for their Conservation. Journal of Livestock Science (ISSN online 2277-6214) 5: 65-78 
(22) Murgueitio RE, Chará JD, Solarte AJ, Uribe F, Zapata C, Rivera JE, 2014. Agroforestería pecuaria y sistemas silvopastoriles intensivos (SSPi) para la adaptación ganadera al cambio climático con sostenibilidad. Revista Colombiana de Ciencias Pecuarias 26: 313-316.

(23) NRC, National Research Council, 2007. Nutrient Requirements of Small Ruminants: Sheep, Goats, Cervids, and New World Camelids, (The National Academies Press, Washington, D.C.).

(24) Pérez-Luna DJ, García-Ángel MC, Albores-Moreno S, Sosa-Rincón R, León-Velasco H, 2011. Productive parameter of coatsheep in an intensive feeding system of central region of Chiapas. Quehacer Científico en Chiapas 1: 7-13.

(25) Quintanilla-Medina JJ, González-Reyna A, Hernández-Meléndez J, Limas-Martínez AG, CarreónPérez A, Martínez-González JC, 2018. Producción de ovinos de pelo bajo condiciones de pastoreo en el noreste de México. Revista de Investigaciones Veterinarias de Perú 29: 544-55. DOI: $10.15381 /$ rivep.v29i2.13863

(26) Rao I, Peters M, Castro A, Schultze-Kraft R, White D, Fisher M, Miles J, Lascano C, Blümmel M, Bungenstab D, Tapasco J, Hyman G, Bolliger A, Paul B, van der Hoek R, Maass B, Tiemann T, Cuchillo M, Douxchamps S, Villanueva C, Rincón A, Ayarza M, Rosenstock T, Subbarao G, Arango J, Cardoso J, Worthington M, Chirinda N, Notenbaert A, Jenet A, Schmidt A, Vivas N, Lefroy R, Fahrney K, Guimarães E, Tohme J, Cook S, Herrero M, Chacón M, Searchinger T, Rudel T, 2015. LivestockPlus - The sustainable intensification of forage-based agricultural systems to improve livelihoods and ecosystem services in the tropics. Tropical Grasslands Forrajes Tropicales 3: 59 - 82. Doi: 10.17138/TGFT(3)59-82.

(27) SIAP - Servicio de Información Agrícola y Pecuaria, 2021. Resumen Nacional - Avance mensual de la producción pecuaria, Año 2020. http://infosiap.siap.gob.mx/repoAvance_siap_gb/pecResumen.jsp. Accesed on 17 February 2021.

(28) Silveira VCP, Álvarez-Rodríguez J, Joy M, Sanz A, Bernués A, 2012. Lamb growth simulation through Pampa Corte model adapted to sheep: Ciência Rural 42: 2066-2070.

(29) Silveira VCP, Casasús I, Blanco M, Joy M, Bernués A, 2011. Evaluation of "Pampa-corte" simulation model in different beef cattle fattening systems in Spain: Ciência Rural 41: 497-500. DOI: $10.1590 / \mathrm{S} 0103-84782011000300022$

(30) Sniffen CJ, Oconnor JD, Van Soest PJ, Fox DG, Russell JB, 1992. A net carbohydrate and protein system for evaluating cattle diets. 2. Carbohydrate and protein availability. Journal of Animal Science 70: 3562-3577.

(31) Tedeshi LO, Cannas A, Fox DG, 2010. A nutrition mathematical model to account for dietary supply and requirements of energy and nutrients for domesticated small ruminants: The development and evaluation of the Small Ruminant Nutrition System. Small Ruminant Research 89: 174-184. DOI: 10.1016/j.smallrumres.2009.12.041

(32) Trevisan NB, Silveira VCP, Ferreira de Quadros FL, Fontoura da Silva AC, 2009. Animal performance simulated by Pampa Corte model with experimental records. Ciência Rural 39: 173181.

(33) Van Soest PJ, 1967. Development of a comprehensive system of feed analyses and its application to forages. Journal of Animal Science 26: 119-128.

(34) Vieira PAS, Pereira LGR, Azevêdo JAG, Neves ALA, Chizzotti ML, dos Santos RD, de Araújo GG, Mistura C, Chaves AV, 2013. Development of mathematical models to predict dry matter intake in feedlot Santa Ines rams. Small Ruminant Research 112: 78-84.

(35) Villanueva-Partida CR, Chay-Canul AJ, Casanova-Lugo F, Juan E, Roo SQ, Tabasco V, 2019. Productive and ingestive behavior in growing hair sheep in silvopastoral and stabled weight-gain systems. Revista Mexicana de Ciencias Pecuarias 10: 870-884. 